\title{
KEBIJAKAN AFIRMATIF BAGI USAHA MIKRO, KECIL DAN MENENGAH DI BIDANG KEKAYAAN INTELEKTUAL
}

\author{
(Affirmative Policy for Micro, Small and Medium Enterprises in the Field of Intellectual Property)
}

\author{
Eka N.A.M. Sihombing \\ Fakultas Hukum Universitas Muhammadiyah Sumatera Utara \\ Jl. Kapten Muchtar Basri No. 3, Medan 20238 \\ E-mail: ekahombing@gmail.com
}

Naskah diterima: 18 Agustus 2018; revisi: 29 Oktober 2018; disetujui: 5 November 2018

\begin{abstract}
Abstrak
Mengingat peran Usaha Mikro, Kecil, Menengah (UMKM) yang sangat strategis dalam perekonomian nasional di mana kegiatan usahanya mampu memperluas lapangan kerja dan memberikan pelayanan ekonomi secara luas kepada masyarakat, maka perlindungan Hak Kekayaan Intelektual (HKI) harus dapat dimanfaatkan secara optimal oleh UMKM. Uraian mengenai kebijakan affirmatif yang seharusnya diberlakukan bagi UMKM di bidang Kekayaan intelektual menjadi obyek yang menarik untuk dikaji. Dengan menggunakan metode penelitian yuridis normatif terhadap pemanfaatan sistem HKI bagi UMKM, hasil kajian menemukan beberapa hambatan dalam pemanfaatan sistem HKI oleh UMKM yang disebabkan karena beberapa faktor, antara lain: prosedur pendaftaran yang panjang dan kompleks, biaya registrasi/ pendaftaran yang mahal dan lemahnya penegakan hukum bagi pelanggaran HKI. Untuk itu perlu diberikan keistimewaan bagi UMKM khususnya di bidang kekayaan intelektual melalui kebijakan-kebijakan affirmatif yang harus segera diwujudkan guna mendukung pemajuan usaha UMKM dengan melakukan percepatan perubahan berbagai peraturan perundangundangan yang terkait dengan HKI.

Kata Kunci: kebijakan afirmatif, Kekayaan Intelektual, UMKM
\end{abstract}

\begin{abstract}
Given the very strategic role of Micro, Small and Medium Enterprises (MSMEs) in the national economy where its business activities are able to expand employment and provide broad economic services to the public, Intellectual Property Rights (IPR) protection must be utilized optimally by MSMEs. Using normative juridical research methods towards the utilization of the IPR system for MSMEs, this research found out there are various obstacles in the use of IPR systems by MSMES due to several factors, such as, long and complex registration procedures, expensive registration/ registration fees and weak enforcement law for IPR violations. For this reason it is necessary to provide privileges for MSMEs, especially in the field of intellectual property through affirmative policies that must be immediately realized to support the promotion of MSME businesses by accelerating changes in various laws and regulations related to IPR.
\end{abstract}

Keywords: affirmative policy, Intellectual Property, MSMEs 


\section{A. Pendahuluan}

Salah satu cita-cita yang hendak dicapai bangsa Indonesia sebagaimana termaktub dalam Pembukaan Undang-Undang Dasar Negara Republik Indonesia (UUDNRI) Tahun 1945 adalah mewujudkan suatu keadilan sosial bagi seluruh rakyat Indonesia, hal ini bermakna bahwa seluruh tumpah darah Indonesia mendapatkan perlakuan yang adil dalam berbagai bidang, tak terkecuali di bidang ekonomi, tidak ada perbedaan strata antara usaha besar dengan usaha mikro, kecil dan menengah (UMKM) di dalamnya, semua usaha yang dilakukan oleh masyarakat mendapatkan hak-hak yang seharusnya diperoleh dengan adil.Untuk mencapai keadilan substantif dan menambal kesenjangan antar kelompok usaha, dapat saja untuk sementara waktu dibuka kemungkinan penerapan kebijakan affirmatif atau perlakuan berbeda dengan memberikan keistimewaan tertentu kepada orang, gender atau profesi tertentu, ${ }^{1}$ hal ini secara konstitusional mendapatkan pembenaran melalui rumusan Pasal 28 H UUDNRI Tahun 1945 yang berbunyi: " Setiap orang berhak mendapat

kemudahan dan perlakuan khusus untuk memperoleh kesempatan dan manfaat yang sama guna mencapai persamaan dan keadilan."

Dalam konteks untuk menumbuhkembangkan iklim usaha, berbagai kebijakan affirmatif bagi UMKM telah diimplementasikan melalui berbagai peraturan perundang-undangan, diantaranya
Undang-Undang Nomor 20 Tahun 2008 tentang Usaha Mikro, Kecil dan Menengah (UU UMKM) yang disusun dengan maksud sebagai upaya untuk meningkatkan kemampuan dan peran serta kelembagaan Usaha Mikro, Kecil, dan Menengah dalam perekonomian nasional. $^{2}$ Dalam ketentuan Pasal 7 UU UMKM ditegaskan bahwa Pemerintah dan Pemerintah Daerah menumbuhkan Iklim Usaha dengan menetapkan peraturan perundangundangan dan kebijakan yang meliputi aspek: $a$. pendanaan; $b$. sarana dan prasarana; $c$. informasi usaha; $d$. kemitraan; $e$. perizinan usaha; $f$. kesempatan berusaha; $g$. promosi dagang; dan $h$. dukungan kelembagaan. Selain itu Pemerintah dan Pemerintah Daerah juga diperintahkan UU UMKM untuk memfasilitasi pengembangan usaha dalam bidang: a. produksi dan pengolahan; b. pemasaran; c. sumber daya manusia; dan d. desain dan teknologi.

Dalam hal menumbuhkan iklim usaha dan fasilitasi pengembangan usaha, Pemerintah dan Pemerintah Daerah memfasilitasi pemilikan hak atas kekayaan intelektual atas produk dan desain Usaha Mikro, Kecil, dan Menengah dalam kegiatan usaha dalam negeri dan ekspor serta mendorong Usaha Mikro, Kecil, dan Menengah untuk memperoleh sertifikat hak atas kekayaan intelektual. $^{3}$

Sebagaimana diketahui bahwa Perlindungan atas Kekayaan Intelektual memiliki arti penting bagi dunia usaha. Kekayaan intelektual merupakan kunci persaingan serta 
pengembangan sebuah usaha. Pemahaman akan Hak Kekayaan Intelektual (HKI) tidak hanya berguna untuk melindungi bisnis, tetapi juga menjaga agar suatu usaha tidak melanggar hukum akibat pelanggaran HKI. ${ }^{4}$ UMKM sebagai pelaku ekonomi nasional yang mempunyai peran yang sangat penting dalam pembangunan perekonomian, ${ }^{5}$ hal ini dikarenakan kegiatan usahanya mampu memperluas lapangan kerja dan memberikan pelayanan ekonomi secara luas kepada masyarakat. ${ }^{6}$ Maka sudah sepatutnya UMKM perlu memperoleh kesempatan yang sama dan bahkan harus diberikan keistimewaan khususnya di bidang kekayaan intelektual. Berdasarkan hal tersebut, maka tulisan ini dimaksudkan untuk mengurai kebijakan affirmatif yang seharusnya diberlakukan bagi UMKM di bidang Kekayaan intelektual.

\section{B. Metode Penelitian}

Metode yang digunakan dalam tulisan ini adalah metode penelitian hukum yuridis normatif. Suatu penelitian normatif, haruslah menggunakan pendekatan perundangundangan (statute Approach), hal ini dikarenakan yang akan diteliti adalah berbagai aturan hukum. ${ }^{7}$

Adapun sifat penelitian yang dipergunakan dalam tulisan ini adalah preskriptif, berpegang pada karakteristik ilmu hukum sebagai ilmu terapan, preskripsi yang diberikan di dalam kegiatan penelitian hukum harus dapat dan mungkin untuk diterapkan. ${ }^{8}$ Oleh karena itu yang dihasilkan oleh penelitian hukum, sekalipun bukan asas hukum yang baru atau teori baru, paling tidak argumentasi baru. ${ }^{9}$

\section{Pembahasan}

\section{Peran UMKM dalam Perekonomian Nasional}

Berdasarkan ketentuan Pasal 1 juncto Pasal 6 Undang Undang Nomor 20 Tahun 2008 disebutkan bahwa :

a. Usaha mikro adalah usaha produktif milik orang perorangan dan/atau badan usaha perorangan yang memenuhi kriteria

4 Berinovasi.com, "Pentingnya Kekayaan Intelektual dalam Dunia Usaha", Berinovasi.com, http://berinovasi. com/wp-content/uploads/2018/01/Ebook-Pentingnya-Kekayaan-Intelektual-dalam-Dunia-Usaha.pdf (diakses 5 Agustus 2018).

5 Candra Purnama, "Perlindungan Hukum Produk UMKM melalui HKI (Hak Kekayaan Intelektual)", Dinkop UMKM Provinsi Jawa Tengah, http://dinkop-umkm.jatengprov.go.id/assets/upload/files/HAK\%20MEREK\%20UMKM. pdf (diakses 5 Agustus 2018)

6 UMKM sebagai salah satu pilar utama ekonomi nasional yang memberikan kontribusi terhadap Produk Domestik Bruto (PDB) yang sangat signifikan, tercatat pada akhir tahun 2017 kontribusi UMKM terhadap PDB nasional adalah Rp 7.005.950 milyar atau sekitar 62,57\% dari total PDB. Lihat : Lei-KO2, "Ini Kontribusi Koperasi dan UMKM Terhadap PDB Nasional 2017", Legal Era.Id, https://legaleraindonesia.com/ini-kontribusi-koperasi-danumkm-terhadap-pdb-nasional-2017/, (diakses 5 Agustus 2018)

7 Peneliti harus melihat hukum sebagai suatu sistem yang tertutup, dengan ciri-ciri sebagai berikut:

- Comprehensive, artinya norma-norma hukum yang ada di dalamnya terkait antara satu dengan yang lainnya secara logis;

- All Inclusive, bahwa kumpulan norma hukum tersebut cukup mampu menampung permasalahan hukum yang ada, sehingga tidak aka nada kekurangan hukum;

- Systematic, bahwa norma-norma hukum tersebut, disamping bertautan antara satu dengan yang lain juga tersusun secara hirarkis.

- Lebih lanjut lihat Joenaidi Efendi dan Johnny Ibrahim, Metode Penelitian Hukum (Normatif dan Empiris), (Jakarta : Prenada Media, 2018), hlm, 132.

8 Peter Mahmud Marzuki, Penelitian Hukum, (Jakarta: Prenada media, 2011), hlm 251.

9 Ibid 
memiliki kekayaan bersih paling banyak Rp50.000.000,00 (lima puluh juta rupiah) tidak termasuk tanah dan bangunan tempat usaha; atau memiliki hasil penjualan tahunan paling banyak Rp300.000.000,00 (tiga ratus juta rupiah).

b. Usaha Kecil adalah usaha ekonomi produktif yang berdiri sendiri, yang dilakukan oleh orang perorangan atau badan usaha yang bukan merupakan anak perusahaan atau bukan cabang perusahaan yang dimiliki, dikuasai, atau menjadi bagian baik langsung maupun tidak langsung dari Usaha Menengah atau Usaha Besar yang memenuhi kriteria memiliki kekayaan bersih lebih dari Rp50.000.000,00 (lima puluh juta rupiah) sampai dengan paling banyak Rp500.000.000,00 (lima ratus juta rupiah) tidak termasuk tanah dan bangunan tempat usaha; atau memiliki hasil penjualan tahunan lebih dari Rp300.000.000,00 (tiga ratus juta rupiah) sampai dengan paling banyak Rp2.500.000.000,00 (dua milyar lima ratus juta rupiah).

c. Usaha Menengah adalah usaha ekonomi produktif yang berdiri sendiri, yang dilakukan oleh orang perorangan atau badan usaha yang bukan merupakan anak perusahaan atau cabang perusahaan yang dimiliki, dikuasai, atau menjadi bagian baik langsung maupun tidak langsung dengan Usaha Kecil atau Usaha Besar dengan kriteria memiliki kekayaan bersih lebih dari Rp500.000.000,00 (lima ratus juta rupiah) sampai dengan paling banyak Rp10.000.000.000,00 (sepuluh milyar rupiah) tidak termasuk tanah dan bangunan tempat usaha; atau memiliki hasil penjualan tahunan lebih dari Rp2.500.000.000,00 (dua milyar lima ratus juta rupiah) sampai dengan paling banyak Rp50.000.000.000,00 (lima puluh milyar rupiah).

Selain menggunakan nilai moneter sebagai kriteria untuk menentukan jenis UMKM, sejumlah lembaga pemerintah, seperti Badan Pusat Statistik (BPS), selama ini juga menggunakan jumlah pekerja sebagai ukuran untuk membedakan skala usaha antara usaha mikro, usaha kecil, usaha menengah dan usaha besar. ${ }^{10}$ Menurut BPS, usaha mikro (atau di sektor industri manufaktur umum disebut industri rumah tangga) adalah unit usaha dengan jumlah pekerja tetap hingga 4 orang, usaha kecil antara 5 hingga 19 pekerja; dan usaha menengah antara 20 sampai dengan 99 pekerja. ${ }^{11}$

Rahmana sebagaimana dikutip Sudaryanto, dkk mengelompokkan UMKM dengan melihat dari sudut pandang perkembangannya dalam beberapa kriteria, yaitu: ${ }^{12}$

a. Livelihood Activities, merupakan Usaha Kecil Menengah yang digunakan sebagai kesempatan kerja untuk mencari nafkah, yang lebih umum dikenal sebagai sektor informal. Contohnya adalah pedagang kaki lima.

b. Micro Enterprise, merupakan Usaha Kecil Menengah yang memiliki sifat pengrajin tetapi belum memiliki sifat kewirausahaan.

\footnotetext{
Ade Irawan Taufik, "Evaluasi Regulasi Dalam Menciptakan Kemudahan Berusaha Bagi UMKM", Jurnal Rechtsvinding Volume 6, Nomor 3, (2017):375.

12 Sudaryanto, et.al., "Strategi Pemberdayaan UMKM Menghadapi Pasar Bebas Asean", Kementerian Keuangan, https://www.kemenkeu.go.id/sites/default/files/strategi\%20pemberdayaan\%20umkm.pdf (diakses 5 Agustus 2018)
}

11 Ibid. 
c. Small Dynamic Enterprise, merupakan Usaha Kecil Menengah yang telah memiliki jiwa kewirausahaan dan mampu menerima pekerjaan subkontrak dan ekspor.

d. Fast Moving Enterprise, merupakam Usaha Kecil Menengah yang telah memiliki jiwa kewirausahaan dan akan melakukan transformasi menjadi Usaha Besar (UB).

\section{Sektor UMKM mempunyai peran yang sangat} strategis dalam perekonomian Indonesia, selain catatan sejarah yang menunjukkan bahwa hanya sektor UMKM yang bertahan dari kolapsnya dari krisis ekonomi yang terjadi pada tahun 1998, sementara sektor usaha yang lebih besar justru tumbang oleh krisis. ${ }^{13}$ Beberapa sebab yang membuat sektor UMKM dapat bertahan di kala krisis tidak terlepas dari karakteristik pelaku UMKM sebagaimana disampaikan Prawirokusumo sebagaimana dikutip Hempri Suyatna, yaitu sebagai berikut: ${ }^{14}$

a. Fleksibel, dalam arti jika menghadapi hambatan dalam menjalankan usahanya akan mudah berpindah ke usaha lain.

b. Dalam permodalannya, tidak selalu tergantungpada modal dari luar, tetapi dia bisa berkembang dengan kekuatan modal sendiri.

c. Dalam hal pinjaman (terutama pengusaha kecil sector tertentu seperti pedagang) sanggup mengembalikan pinjaman dengan bunga yang cukup tinggi.

d. UMKM tersebar di seluruh Indonesia dengan kegiatan usaha di berbagai sektor, merupakan sarana dan distributor barang dan jasa dalam melayani kebutuhan masyarakat.

Tak hanya itu, lebih lanjut menurut Hempri Suyatna saat ini sektor produktif UMKM telah mampu membuktikan diri sebagai salah satu solusi pertumbuhan angkatan kerja baru di Indonesia yang sangat tinggi. ${ }^{15}$ Perannya yang sangat signifikan dalam penyerapan tenaga kerja itu menjadikan UMKM sangat efektif menjadi piranti memperkuat stabilitas nasional. ${ }^{16}$ Tercatat sektor produktif UMKM dapat mempekerjakan lebih dari 107,6 juta penduduk Indonesia. ${ }^{17}$ Selain itu UMKM juga berkontribusi dan berkorelasi dengan pertumbuhan ekonomi di daerah, hal ini dapat dilihat dari salah satu hasil penelitian yang diuraikan oleh Nining Sudiyarti, dkk. ${ }^{18}$ yang mengambil sampel di Kabupaten Sumbawa. Dalam kesimpulan penelitian tersebut dinyatakan bahwa variabel UMKM berkolerasi dan mempunyai pengaruh yang signifikan dan positif terhadap variabel pertumbuhan ekonomi khususnya di kabupaten Sumbawa. UMKM juga memberi kontribusi yang besar dalam perekonomian di Jawa Timur, di mana berdasarkan fakta empiris di lapangan

13 Pradnya Paramita Hapsari, et.al, "Pengaruh Pertumbuhan Usaha Kecil Menengah (UKM) terhadap Pertumbuhan Ekonomi Daerah (Studi di Pemerintah Kota Batu)", Jurnal Wacana Volume 17, Nomor 2 (2014):89.

14 Hempri Suyatna, "Peran Strategis UMKM dan Tantangan di Era Globalisasi", dalam Rachmawan Budiarto, et.al.,, Pengembangan UMKM antara Konseptual dan Pengalaman Praktis, (Yogyakarta : Gadjah Mada University Press, 2015), hlm 5 .

15 Ibid., hlm. 4.

16 Ibid.

17 Putri Syifa Nurfadilah, "UMKM Mampu Dongkrak Pertumbuhan Ekonomi" , Kompas.com, https://ekonomi. kompas.com/read/2018/07/10/200246326/umkm-mampu-dongkrak-pertumbuhan-ekonomi (diakses 5 Agustus 2018).

18 Lebih lanjut lihat Nining Sudiyarti, et.al., "Pengaruh Usaha Mikro Kecil Menengah (UMKM) Terhadap Pertumbuhan Ekonomi Daerah Kabupaten Sumbawa Tahun 2011-2015", Jurnal Ekonomi dan Bisnis, Volume 14 Nomor 2 (2017). 
dalam lima tahun terakhir share terhadap pertumbuhan ekonomi nasional semakin meningkat, dari 19,91 persen pada tahun 2013 meningkat menjadi 21,70 persen pada tahun 2017. ${ }^{19}$

Di Yogyakarta, UMKM masih menjadi penopang utama perekonomian, daya tahan UMKM membuat pertumbuhan ekonominya tumbuh di atas ekonomi Indonesia. Bahkan kontribusi UMKM terhadap perekonomian Yogyakarta mencapai 94,6 persen. ${ }^{20}$ Sedangkan di Kota Bogor, sektor UMKM menjadi tumpuan bagi pertumbuhan ekonomi, Selama 2017, UMKM menyumbang 70 persen dari seluruh pendapatan asli daerah Kota Bogor. ${ }^{21}$ Secara nasional UMKM memberikan kontribusi terhadap PDB nasional 2017 sekitar 62,57\% dari total PDB. ${ }^{22}$

Lebih lanjut Supriyanto menguraikan beberapa keunggulan UMKM terhadap usaha besar, antara lain: ${ }^{23}$

a. Inovasi dalam teknologi yang telah dengan mudah terjadi dalam pengembangan produk.

b. Hubungan kemanusiaan yang akrab didalam perusahaan kecil. c. Kemampuan menciptakan kesempatan kerja cukup banyak atau penyerapannya terhadap tenaga kerja.

d. Fleksibilitas dan kemampuan menyesuaikan diri terhadap kondisi pasar yang berubah dengan cepat dibanding dengan perusahaan skala besaryang pada umumnya birokratis.

e. Terdapatnya dinamisme managerial dan peranan kewirausahaan

Berbagai data dan fakta tersebut diatas, membuktikan bahwa UMKM menjadi salah satu elemen penting dalam perekonomian nasional. Posisi seperti itu menempatkan peran UMKM sebagai salah satu sokoguru pengembangan sistem ekonomi kerakyatan sebagai wujud bangunan ekonomi nasional. ${ }^{24}$

\section{Pentingnya HKI bagi UMKM}

Sesuai dengan perkembangan zaman, pengaturan terhadap hak-hak yang dimiliki oleh setiap manusia termasuk halnya dengan Hak Kekayaan Intelektual (HKI) merupakan sebuah keniscayaan. ${ }^{25} \mathrm{HKI}$ atau Intellectual Property Rights (IPR) merupakan hak yang lahir

19 Sri Handi Lestari, "Kontribusi UMKM terhadap Pertumbuhan Ekonomi Jatim Diklaim Terus Tumbuh Positif", Surabaya Tribun News, http://surabaya.tribunnews.com/2018/06/22/kontribusi-umkm-terhadappertumbuhan-ekonomi-jatim-diklaim-terus-tumbuh-positif (diakses 1 Oktober 2018).

20 Arif Wicaksono, "UMKM Dongkrak Pertumbuhan Ekonomi Yogyakarta Lampaui Nasional", MetroTV News, http://ekonomi.metrotvnews.com/mikro/8N0V8mAk-umkm-dongkrak-pertumbuhan-ekonomi-yogyakartalampaui-nasional (diakses 01 Oktober 2018).

21 Lihat "Ini Kontribusi Koperasi dan UMKM terhadap PDB Nasional 2017", https://legaleraindonesia.com/inikontribusi-koperasi-dan-umkm-terhadap-pdb-nasional-2017/ (diakses 05 Agustus 2018).

22 Supriyanto, "Pemberdayaan Usaha Mikro, Kecil, dan Menengah (UMKM) Sebagai Salah Satu Upaya Penanggulangan Kemiskinan", Jurnal Ekonomi dan Pendidikan, Volume 3 Nomor 1, (2006):1.

23 Hempri Suyatna, "Peran Strategis UMKM dan Tantangan di Era Globalisasi", dalam Rachmawan Budiarto, et.al.,, Pengembangan UMKM antara Konseptual dan Pengalaman Praktis, (Yogyakarta : Gadjah Mada University Press, 2015), hlm 4.

24 Hempri Suyatna, "Peran Strategis UMKM dan Tantangan di Era Globalisasi", dalam Rachmawan Budiarto, et.al.,, Pengembangan UMKM antara Konseptual dan Pengalaman Praktis, (Yogyakarta : Gadjah Mada University Press, 2015), hlm 4.

25 Djulaeka, Konsep Perlindungan Hak Kekayaan Intelektual (Perspektif Kajian Filosofis HaKI Kolektif Komunal), (Malang : Setara Press, , 2014), hlm 1 
dari hasil olah pikir manusia yang diwujudkan dalam bentuk karya intelektual. Wiradirja dan Munzil menyatakan bahwa HKI merupakan hak yang berasal dari hasil kegiatan kreatif suatu kemampuan daya pikir manusia yang memiliki manfaat serta berguna dalam menunjang kehidupan manusia, juga mempunyai nilai ekonomi. ${ }^{26}$ Mengingat HKI merupakan hasil kegiatan kreatif, maka sudah sepatutnya HKI perlu mendapatkan perlindungan secara hukum. Robert M. Sherwood sebagaimana dikutip Wiradirja dan Munzil mengemukakan berbagai teori yang mendasari perlunya perlindungan hukum bagi HKI, yaitu :27

1. Reward Theory, yang memiliki makna yang sangat mendalam terhadap karya intelektual yang telah dihasilkan oleh seseorang sehingga kepada penemu/pencipta atau pendesain harus diberikan penghargaan sebagai imbangan atas upaya-upaya kreatifnya dalam menemukan/ menciptakan karya karya intelektual tersebut.

2. Recovery Theory, menyatakan bahwa penemu/pencipta atau pendesain yang telah mengeluarkan waktu, biaya serta tenaga dalam menghasilkan karya intelektualnya harus memperoleh kembali apa yang telah dikeluarkannya tersebut.

3. Incentive Theory, yang mengaitkan pengembangan kreatifitas dengan memberikan insentif perlu diberikan untuk mengupayakan terpacunya kegiatankegiatan penelitian yang berguna.

4. Risk Theory, bahwa HKI merupakan suatu hasil karya yang mengandung risiko. HKI yang merupakan hasil dari suatu penelitian mengandung risiko yang dapat memungkinkan orang lain yang terlebih dahulu meneumkan cara tersebut atau memperbaikinya sehingga dengan demikian adalah wajar untuk memberikan perlindungan hukum terhadap upaya atau kegiatan yang mengandung risiko.

5. Economic Growth Stimulus Theory, teori ini mengakui bahwa perlindungan atas HKI merupakan suatu alat dari pembangunan ekonomi dan yang dimaksud dengan pembangunan ekonomi adalah keseluruhan tujuan dibangunnya suatu sistem perlindungan atas HKI yang efektif.

Berbagai teori yang dikemukakan tersebut, semakin memperkuat pemahaman bahwa HKI merupakan objek yang sangat perlu mendapatkan perlindungan hukum, tanpa perlindungan hukum yang memadai maka dapat dipastikan akan mempengaruhi laju kreatifitas suatu Negara dalam melahirkan karya-karya baru. Kotler sebagaimana dikutip Sean Matthew menyatakan bahwa HKI merupakan salah

26 Imas Rosidawati Wiradirja dan Fontian Munzil, Pengetahuan Tradisional dan Hak Kekayaan Intelektual (Perlindungan Pengetahuan Tradisional Berdasarkan Asas Keadilan Sui Generis Intellectual Property System), (Bandung : Refika Aditama, 2018), hlm 30.

27 Ibid.

28 Menurut Kotler beberapa modal yang menjadi faktor yang mempengaruhi kesejahteraan suatu bangsa ialah pertama: Natural Capital (modal alami) ; air, tanah, kayu, mineral dan sebagainya, kedua: Physical Capital (modal fisik) ; Mesin, bangunan, pabrik, fasilitas publik lainnya, ketiga: Human Capital (modal insani); nilai produktif manusia, Hak Kekayaan Intelektual (HKI) dan keempat: Social Capital (modal sosial): nilainilai keluarga, masyarakat, berbagai organisasi yang dibentuk dalam masyarakat. Lihat Sean Matthew, "Analisis Terhadap Pengaturan Hukum Hak Merek Yang Dijaminkan Melalui Mekanisme Fidusia", Kanal Hukum, http://kanalhukum.id/kanalis/analisis-terhadap-pengaturan-hukum-hak-merek-yang-dijaminkan-melaluimekanisme-fidusia/43 (diakses 6 Agustus 2018) 
satu modal yang menjadi faktor berpengaruh terhadap kesejahteraan suatu bangsa. ${ }^{28}$

Secara garis besar HKI dipilah menjadi 2 (dua) bagian, yaitu Hak Cipta (copyrights) meliputi hak cipta dan hak-hak yang terkait (neighbouring right) sertaHak Kekayaan Industri (Industrial Property Rights) meliputi merek, paten, desain industri, rahasia dagang, desain tata letak sirkuit terpadu, ${ }^{29}$ secara rinci dapat digambarkan sebagai berikut:

Tabel 1. Jenis Kekayaan Intelektual dan Lingkup Perlindungannya

\begin{tabular}{|c|c|c|c|}
\hline No & $\begin{array}{l}\text { Jenis Kekayaan } \\
\text { Intelektual }\end{array}$ & Lingkup Perlindungan & Dasar Hukum \\
\hline 1 & Cipta & Seni, Sastra dan Ilmu Pengetahuan & $\begin{array}{l}\text { Undang - Undang Nomor } 28 \\
\text { Tahun } 2014 \text { tentang Hak Cipta }\end{array}$ \\
\hline 2 & Merek & $\begin{array}{l}\text { Tanda yang dapat ditampilkan secara grafis } \\
\text { berupa gambar, logo, nama, kata, huruf, angka, } \\
\text { susunan warna, dalam bentuk } 2 \text { (dua) dimensi } \\
\text { dan/atau } 3 \text { (tiga) dimensi, suara, hologram, atau } \\
\text { kombinasi dari } 2 \text { (dua) atau lebih unsur tersebut } \\
\text { untuk membedakan barang dan/atau jasa yang } \\
\text { diproduksi oleh orang atau badan hukum dalam } \\
\text { kegiatan perdagangan barang dan/atau jasa }\end{array}$ & $\begin{array}{l}\text { Undang - Undang Nomor } 20 \\
\text { Tahun } 2016 \text { tentang Merek dan } \\
\text { Indikasi Geografis }\end{array}$ \\
\hline 3 & $\begin{array}{l}\text { Indikasi } \\
\text { Geografis }\end{array}$ & $\begin{array}{l}\text { Suatu tanda yang menunjukkan daerah asal } \\
\text { suatu barang dan/atau produk yang karena faktor } \\
\text { lingkungan geografis termasuk faktor alam, faktor } \\
\text { manusia, atau kombinasi dari kedua faktor tersebut } \\
\text { memberikan reputasi, kualitas, dan karakteristik } \\
\text { tertentu pada barang dan/atau produk yang } \\
\text { dihasilkan }\end{array}$ & $\begin{array}{l}\text { Undang - Undang Nomor } 20 \\
\text { Tahun } 2016 \text { tentang Merek dan } \\
\text { Indikasi Geografis }\end{array}$ \\
\hline 4 & Paten & Invensi di bidang Teknologi & $\begin{array}{l}\text { Undang - Undang Nomor } 13 \\
\text { Tahun } 2016 \text { tentang Paten }\end{array}$ \\
\hline 5 & $\begin{array}{l}\text { Rahasia } \\
\text { Dagang }\end{array}$ & $\begin{array}{l}\text { informasi yang tidak diketahui oleh umum di } \\
\text { bidang teknologi dan/atau bisnis, mempunyai nilai } \\
\text { ekonomi karena berguna dalam kegiatan usaha, } \\
\text { dan dijaga kerahasiaannya oleh pemilik Rahasia } \\
\text { Dagang }\end{array}$ & $\begin{array}{l}\text { Undang - Undang Nomor } 30 \\
\text { Tahun } 2000 \text { tentang Rahasia } \\
\text { Dagang }\end{array}$ \\
\hline 6 & Desain Industri & $\begin{array}{l}\text { Suatu kreasi tentang bentuk, konfigurasi, atau } \\
\text { komposisi garis atau warna, atau garis dan warna, } \\
\text { atau gabungan daripadanya yang berbentuk tiga } \\
\text { dimensi atau dua dimensi yang memberikan } \\
\text { kesan estetis dan dapat diwujudkan dalam pola } \\
\text { tiga dimensi atau dua dimensi serta dapat dipakai } \\
\text { untuk menghasilkan suatu produk, barang, } \\
\text { komoditas industri, atau kerajinan tangan }\end{array}$ & $\begin{array}{l}\text { Undang - Undang Nomor } 31 \\
\text { Tahun } 2000 \text { tentang Desain } \\
\text { Industri }\end{array}$ \\
\hline
\end{tabular}

29 Endang Purwaningsih, Hak Kekayaan Intelektual (HKI) dan Lisensi, (Bandung : Mandar Maju, 2012), hlm 3. 
7 Desain Tata $\quad$ suatu produk dalam bentuk jadi atau setengah Letak Sirkuit Terpadu jadi, yang di dalamnya terdapat berbagai elemen dan sekurang-kurangnya satu dari elemen tersebut adalah elemen aktif, yang sebagian atau seluruhnya saling berkaitan serta dibentuk secara terpadu di dalam sebuah bahan semikonduktor yang dimaksudkan untuk menghasilkan fungsi elektronik

- kreasi berupa rancangan peletakan tiga dimensi dari berbagai elemen, sekurangkurangnya satu dari elemen tersebut adalah elemen aktif, serta sebagian atau semua interkoneksi dalam suatu Sirkuit Terpadu dan peletakan tiga dimensi tersebut dimaksudkan untuk persiapan pembuatan Sirkuit Terpadu.
HKI merupakan sumber kekayaan material bagi pemiliknya, dan salah satu aspek hak khusus pada HKI adalah hak ekonomi (economy rights). ${ }^{30}$ Hak ekonomi adalah hak untuk memperoleh keuntungan ekonomiatas kekayaan intelektual. ${ }^{31}$ Hak ekonomi itu diperhitungkan karena HKI dapat digunakan/dimanfaatkan oleh pihak lain dalam perindustrian atau perdagangan yang mendatangkan keuntungan, dengan kata lain HKI adalah objek perdagangan. ${ }^{32}$ Dalam kegiatan industri dan perdagangan, keuntungan ekonomi tidak hanya dapat dinikmati oleh pemilik tetapi juga oleh pihak lain. ${ }^{33}$ Cara memperoleh keuntungan ekonomi tersebut, antara lain: ${ }^{34}$

a. HKI digunakan untuk menjalankan suatu bisnis tertentu bagi pemiliknya sendiri, misalnya merek dagang dan merek jasa.

b. HKI diwujudkan dalam bentuk model rancang bangun suatu produk industri kemudian dipasarkan kepada para konsumen, misalnya karya arsitektur. c. HKI dialihkan pemanfaatannya kepada pihak lain melalui lisensi (izin) sehingga pemilik memperoleh keuntungan ganda dari penggunaan sendiri dan dari lisensi misalnya hak cipta dilisensikan kepada produser, hak merek dilisensikan kepada perusahaan perdagangan, paten dilisensikan kepada perusahaan industri.

Dalam konteks UMKM, HKI memiliki pengaruh positif, paling tidak terdapat beberapa manfaat yang dapat dilihat dari sisi ekonomi, perlindungan hukum maupun dari sisi pemacu kreatifitas, antara lain : $:^{35}$

a. Sebagai Aset Perusahaan, HKI merupakan salah satu kunci pendukung agar usaha dapat sukses karena dapat digunakan sebagai aset finansial perusahaan. HKI dapat dieksploitasi oleh pemiliknya melalui penjualan, lisensi, pengalihan atau dapat juga dijadikan sebagai sarana perencanaan

\footnotetext{
30 Abdul Kadir Muhammad, Kajian Ekonomi Hak Kekayaan Intelektual, (Bandung : Citra Aditya Bakti, 2007 ),hlm 23.

31 Ibid.

2 Ibid.

3 Ibid., hlm 14.

4 Ibid.

35 Direktorat Jenderal Hak Kekayaan Intelektual - Departemen Kehakiman dan HAM RI, Membangun Usaha Kecil Menengah Berbasis Pendayagunaan Sistem Hak Kekayaan Intelektual (Kiat Melindungi Usaha), (Jakarta : DJHKIAPEC-IPAustralia, 2004), hlm 13-14.
} 
modal. Bahkan Paten inventor/industriawan karena menjanjikan keuntungan yang tidak kecil, dan dapat dimanfaatkan sebagai sarana untuk memperolehkan/menambah modal/keuntungan.

b. Sebagai Pendukung Pengembangan Usaha, Sebuah usaha yang dalam memproduksi produk/jasa tertentu senantiasa mengupayakan untuk mempertahankan agar kualitas produk/jasa yang dihasilkannya selalu baik, dijamin akan segera meraih kepercayaan masyarakat. Untuk menarik perhatian masyarakat dan sekaligus memperkenalkannya secara cepat dan taktis penggunaan merek tertentu diharapkan dapat merealisasikan keinginnan itu. Produk berbasis HKI yang telah dipercaya oleh masyarakat akan mampu mendukung pengembangan usaha lebih lanjut. Pengembangan usaha yang dapat dilakukan tidak hanya mencakup peningkatan jumlah produksi produk/jasa tersebut. melainkan dapat juga berkembang dalam bentuk produk-produk/jasa-jasa lain, atau pun dengan semakin meningkatnya jumlah tempat usaha.

c. Sebagai Perlindungan Hukum dan Pencegah Persaingan Usaha tidak sehat serta Peningkat Daya Saing, Setiap bisnis/ usaha tidak akan terlepas dari persaingan, baik dalam skala lokal, regional, maupun internasional. Dengan tersedianya sistem HKI diharapkan timbulnya persaingan yang tidak sehat dapat dicegah/ditiadakan. Dalam prakteknya, sistem perlindungan HKI jarang digunakan untuk melarang para pesaing untuk memproduksi barang/jasa yang sama/mirip. Sebaliknya, melalui sistem tersebut, upaya untuk membatas para pesaing dilakukan dengan menawarkan kemungkinan untuk memperoleh lisensi. Melalui mekanisme ini, diharapkan pendistribusian produk dan teknologi terkait kepada penerima lisensi dapat dilakukan. Pada saat yang sama, imbalan royalti yang sepadan diharapkan bisa diperoleh pemilik HKI.Produk, jasa dan hasil karya lain yang memberdayakan sistem HKI dan telah dipercaya oleh masyarakat tidak hanya akan mendukung pengembangan usaha lebih lanjut melainkan juga dapat meningkatkan daya saing dan meraih pasar yang lebih luas.

d. Sebagai Pemacu Inovasi dan Kreatifitas, HKI merupakan hak eksklusif yang dibebankan oleh negara sebagai penghargaan atas hasilkarya intelektual seseorang. Melalui penghargaan tersebut inventor/kreator diharapkan akan terpacu/terangsang untuk berinovasi dalam mengembangkan lebih lanjut karya intelektualnya.

e. Sebagai Image Building, Suatu produk berkualitas yang dilindungi HKI akan mudah dikenal dan digemari masyarakat. Selanjutnya, penggunaan HKI secara terus menerus akan membentuk image terhadap produk terkait.

Mengingat UMKM yang sangat strategis dalam perekonomian nasional, perlindungan HKI harus dapat dimanfaatkan secara optimal oleh UMKM, karena tanpa disadari, produkproduk yang diproduksi oleh UMKM di Indonesia banyak yang bernilai ekonomi tinggi dan memiliki keunikan terutama apabila sudah masuk dalam pasar perdagangan. ${ }^{36} \mathrm{Hal}$ ini pula

Bisnis UKM, "Pentingnya HKI bagi UKM", Bisnis UKM, https://bisnisukm.com/pentingnya-hki-bagi-ukm.html (diakses 6 Agustus 2018). 
yang dapat memicu ketertarikan pihak yang tidak memiliki itikad baik untuk meniru produk tersebut yang kemudian didaftarkan oleh si peniru yang pada akhirnya UMKM tersebut tidak lagi dapat menggunakan produk yang telah didaftarkan oleh si peniru tersebut.

\section{Kebijakan Afirmatif bagi UMKM di bidang HKI}

Dari hasil observasi ${ }^{37}$ dan penelitian menunjukkan bahwa masih banyak UMKM yang enggan untuk memanfaatkan sistem $\mathrm{HKI}$, adapun beberapa faktor penyebab keengganan UMKM untuk memanfaatkan sistem HKI sebagaimana diuraikan oleh Selvie Sinaga, yaitu: ${ }^{38}$ Pertama, Prosedur pendaftaran yang panjang dan kompleks; Kedua, Biaya registrasi/pendaftaran yang mahal; dan Ketiga, Lemahnya penegakan hukum bagi pelanggaran HKI. Lebih lanjut dapat diurai sebagai berikut : Pertama, berkaitan dengan prosedur pendaftaran yang panjang dan kompleks, meskipun beberapa regulasi di bidang Kekayaan Intelektual saat ini telah memangkas jangka waktu, seperti halnya dalam pendaftaran Merek $^{39}$ dapat ditelusuri dalam Naskah Akademik RUU tentang Merek bahwa salah satu alasan perlunya penyederhanaan waktu dikarenakan Proses permohonan Merek yang berlaku pada saat UU Nomor 15 Tahun 2001 tentang Merek dianggap masih kurang efektif dan memakan waktu cukup lama, sehingga diperlukan penyederhanaan waktu proses pendaftaran. ${ }^{40}$ Namun dalam praktiknya proses pendaftaran hingga penerbitan sertifikat relatif lebih lama daripada waktu yang ditentukan. ${ }^{41}$ Lamanya jangka waktu yang ditentukan tersebut juga tidak menjamin permohonan tersebut dikabulkan. Selain itu, dalam hal tempat pendaftaran, selain hak cipta ${ }^{42}$ pendaftaran HKI hanya dapat dilakukan melalui Direktorat

37 Informasi mengenai berbagai faktor penghambat yang dialami oleh UMKM dalam pemanfaatan sistem HKI didapatkan Penulis setelah dalam kurun 2010 sampai dengan saat ini menjadi narasumber dalam berbagai kegiatan seminar HKI khususnya bagi UMKM yang diselenggarakan oleh berbagai instansi.

38 V. Selvie Sinaga, "Faktor-Faktor Penyebab Rendahnya Penggunaan Hak Kekayaan Intelektual di Kalangan Usaha Kecil Menegah Batik", Jurnal Hukum Ius Quia Iustum, Volume 21, Nomor 1 (2014):71.

39 Jangka waktu proses pendaftaran hingga penerbitan sertifikat merek berdasarkan ketentuan UU Nomor 20 Tahun 2016 tentang Merek dan Indikasi Geografis memakan waktu sekitar 9 (sembilan). Adapun Jangka waktu proses pendaftaran hingga penerbitan sertifikat Paten biasa berdasarkan ketentuan UU Nomor 13 Tahun 2016 tentang Paten memakan waktu sekitar 3 (tiga) tahun.

40 Penyederhanaan waktu proses pendaftaran dilakukan dengan cara pelaksanaan pengumuman sebelum dilakukan permeriksaan substantif apabila permohonan sudah diterima secara lengkap. Lebih lanjut apabila terdapat keberatan terhadap permohonan Merek yang diumumkan, maka sekaligus materi keberatan dimaksud dijadikan bahan untuk melakukan pemeriksaan substantif, sehingga proses pemeriksaan permohonan pendaftaran Merek akan menjadi lebih singkat. Lebih lanjut lihat Kementerian Hukum dan HAM RI, Draft Naskah Akademik Peraturan Perundang-Undangan RUU Tentang Merek, (Jakarta : BPHN-Kemenkumham RI, 2015), hlm 69.

41 Sebagai contoh Pengajuan permohonan merek pemohon dengan nomor permohonan merek:

- D022016XXXXXX tanggal penerimaan 19 Desember 2016;

- D022017XXXXXX tanggal penerimaan 11 Desember 2017;

- $\quad$ sampai saat ini (10/18) sertifikat merek nya belum juga diterima oleh si pemohon (sumber diambil dari pangkalan data KI melalui http://pdki-indonesia.dgip.go.id. dan informasi yang langsung diberikan oleh pemohon).

42 Untuk pendaftaran Hak cipta, selain ke Direktorat Jenderal Kekayaan Intelektual, Kantor Wilayah Kementerian Hukum dan HAM yang terdapat di setiap Provinsi dan Konsultan HKI masyarakat dapat mendaftarkan melalui Kementerian/Lembaga, Pemerintah Daerah, Lembaga Pendidikan, Lembaga Penelitian dan Pengembangan, Sentra HKI, UMKM, institusi lain, badan hukum dan Perorangan yang telah memiliki akun resmi yang diberikan oleh Direktorat Jenderal Kekayaan Intelektual. 
Jenderal Kekayaan Intelektual, Kantor Wilayah Kementerian Hukum dan HAMyang terdapat di setiap Provinsi dan Konsultan HKI. Sehingga, tidak semua UMKM yang tersebar di berbagai wilayah dapat dengan mudah untuk mengakses pendaftaran tersebut.

Kedua,berdasarkan ketentuan Peraturan Pemerintah Nomor 45 Tahun 2016 Perubahan Kedua atas Peraturan Pemerintah Nomor 45 Tahun 2014 tentang Jenis dan Tarif atas Jenis Penerimaan Negara Bukan Pajak yang berlaku pada Kementerian Hukum dan Hak Asasi Manusia, UMKM mendapatkan keringanan biaya pendaftaran $\mathrm{HKI}$, akan tetapi biaya tersebut masih dianggap memberatkan khususnya bagi usaha mikro dan kecil ${ }^{43}$, bahkan apabila suatu permohonan ditolak uang pendaftaran yang telah dikeluarkan oleh pemohon tidak dikembalikan.secara rinci biaya pendaftaran HKI dapat diuraikan sebagai berikut:

Tabel 2. Daftar biaya pendaftaran HKI berdasarkan Peraturan Pemerintah Nomor 45 Tahun 2016 Tentang Perubahan Kedua atas Peraturan Pemerintah Nomor 45 Tahun 2014 Tentang Jenis dan Tarif Atas Jenis Penerimaan Negara Bukan Pajak yang Berlaku pada Kementerian Hukum dan Hak Asasi Manusia

\begin{tabular}{|c|c|c|c|}
\hline \multirow{2}{*}{ No } & \multirow{2}{*}{$\begin{array}{l}\text { Jenis HKI } \\
\text { Per Permohonan }\end{array}$} & \multicolumn{2}{|c|}{ Biaya Permohonan Pendaftaran } \\
\hline & & UMKM & Non UMKM \\
\hline \multirow[t]{3}{*}{1} & Cipta & & \\
\hline & a. Secara elektronik (On line) & a. 200.000 & a. 400.000 \\
\hline & b. Secara non elektronik (manual) & b. 250.000 & b. 500.000 \\
\hline \multirow[t]{7}{*}{2} & Desain Industri & & \\
\hline & a. Secara elektronik (On line) & & \\
\hline & 1. Satu desain industri & 1. 250.000 & 1. 800.000 \\
\hline & 2. Satu kesatuan desain & 2. 550.000 & 2. 1.250 .000 \\
\hline & b. Secara non elektronik (manual) & & \\
\hline & 1. Satu desain industri & 1. 300.000 & 1. 1.000 .000 \\
\hline & 2. Satu kesatuan desain & 2. 600.000 & 2. 1.500 .000 \\
\hline \multirow[t]{3}{*}{3} & Paten & & \\
\hline & a. Secara elektronik (On line) & a. 350.000 & a. 1.250 .000 \\
\hline & b. Secara non elektronik (manual) & b. 450.000 & b. 1.500 .000 \\
\hline \multirow[t]{3}{*}{4} & Paten Sederhana & & \\
\hline & a. Secara elektronik (On line) & a. 200.000 & a. 800.000 \\
\hline & b. Secara non elektronik (manual) & b. 250.000 & b. 1.250 .000 \\
\hline 5 & Desain Tata Letak Sirkuit Terpadu & 100.000 & 200.000 \\
\hline
\end{tabular}

43 Hasil wawancara dengan beberapa UMKM pada saat kegiatan Sosialisasi HAKI bagi UMKM di Kabupaten Deli Serdang T.A. 2018 pada hari Selasa 15 Mei 2018 dan Pada Kegiatan Bimtek HaKI dan Labelisasi Halal di Kabupaten Serdang Bedagai T.A. 2018 pada tanggal 03 Juli 2018. 
6 Merek
a. Secara elektronik (On line)
a. $\quad 500.000$
a. $\quad 1.800 .000$
b. Secara non elektronik (manual)
b. 600.000
b. 2.000 .000

7

Indikasi Geografis
a. Secara elektronik (On line)
a. 450.000
c. 450.000
b. Secara non elektronik (manual)
b. 500.000
d. 500.000

Walaupun selama ini lembaga pemerintah maupun pemerintah daerah mempunyai program pemberian insentif dengan memberikan bantuan secara cuma-cuma bagi UMKM untuk mendaftarkan HKI, akan tetapi jumlah pemberian insentif tersebut tidak mampu mengimbangi laju pertumbuhan dan menjangkau seluruh UMKM yang ada di Indonesia. Sebagai gambaran, Kementerian Koperasi dan UKM (Kemenkop UKM) sepanjang tahun 2017 telah memfasilitasi 3000 (tiga ribu) lebih pelaku UMKM untuk mendapatkan HKI. ${ }^{44}$ Padahal di Provinsi Sumatera Utarapertumbuhan UMKM pada tahun 2013 sampai dengan tahun 2017 mengalami peningkatan, pada tahun 2017 jumlah UMKM yang terdapat di Sumatera Utara saja berjumlah 2.857.124 ${ }^{45}$, dan dukungan Perolehan Hak Merk, Hak Paten dan HKI Bagi Usaha Kecil sampai dengan April 2018 di Sumatera Utara sebanyak $330^{46}$, sehingga wajar saja apabila masih sangat banyak UMKM yang tidak terfasilitasi oleh program insentif tersebut.

Ketiga, berkaitan dengan adanya anggapan bahwa penegakan hukum bagi pelanggaran
HKI sangat lemah, hal ini dapat difahami dikarenakan masyarakat kurang memahami bahwa seluruh delik pidana yang terdapat dalam berbagai Undang-Undang di bidang HKI merupakan delik aduan, sehingga ketika terjadi pelanggaran $\mathrm{HKI}$, apabila si pemegang $\mathrm{HKI}$ tidak melakukan pengaduan kepada penegak hukum, maka perkara tersebut tidak dapat diproses lebih lanjut. Penyidik Pegawai Negeri Sipil (PPNS) Bidang Kekayaan Intelektual pada Kanwil Kementerian Hukum dan HAM Sumatera Utara juga menyatakan bahwa PPNS tidak dapat menindaklanjuti ketika menemukan dugaan pelanggaran $\mathrm{HKI}$ yang tidak diadukan oleh si pemilik $\mathrm{HKI}^{47}$ dan bahkan dalam kurun tahun 2015-2018 PPNS Bidang Kekayaan Intelektual pada Kanwil Kementerian Hukum dan HAM Sumatera Utara sama sekali tidak pernah menangani pelanggaran HKI. ${ }^{48}$ Pertimbangan utama delik aduan adalah memberikan hak yang lebih kuat kepada pemegang HKI ketika berperkara. ${ }^{49}$

Sehubungan dengan Peran UMKM yang sangat signifikan dalam memajukan

\footnotetext{
44 Maizal Walfajri, "3000 UKM dapat Fasilitas Hak Cipta dan Merek Gratis", Kontan http://keuangan.kontan.co.id/ news/3000-ukm-dapat-fasilitas-hak-cipta-merek-gratis (diakses 5 Agustus 2018).

45 "Paparan Kepala Dinas Koperasi dan UKM Provinsi Sumatera Utara pada Rakornas Bidang KUMKM Tahun 2018" http://www.depkop.go.id/uploads/tx_rtgfiles/10._Paparan_Rakornas_Yogyakarta_2018_-_Sumatera_Utara.pdf (diakses 6 Agustus 2018).

46 Ibid.

47 Hasil Wawancara dengan Ibu Juraini Sulaiman dan Ali Marwan yang merupakan PPNS bidang Kekayaan Intelektual pada Kanwil Kementerian Hukum dan HAM Sumatera Utara pada tanggal 03 Oktober 2018.

48 Sumber data dari Bidang Pelayanan Hukum Kanwil Kementerian Hukum dan HAM Sumatera Utara.

49 LEI-02, "Ini dia yang sering dilanggar dalam bidang Kekayaan Intelektual”, Legal Era id., https://legaleraindonesia. com/ini-dia-yang-sering-dilanggar-dalam-bidang-hak-kekayaan-intelektual/ (diakses 6 Agustus 2018)
} 
perekonomian nasional, maka sudah seharusnya pemerintah maupun pemerintah daerah melahirkan kebijakan-kebijakan yang bersifat affirmatif bagi UMKM tidak terkecuali di bidang HKI. Agar setiap warga negara memiliki kemampuan yang sama dalam memperoleh perlindungan dan pemenuhan hak konstitusional yang sama pula, diperlukan perlakuan khusus terhadap kelompok tertentu. ${ }^{50}$ Hanya dengan perlakuan khusus atau tindakan affirmatif tersebut, dapat dicapai persamaan perlakuan dalam perlindungan dan pemenuhan hak konstitusional setiap warga negara.Hendri Sayuti menyatakan bahwa tindakan affrimatif ini merupakan jalan yang banyak dipilih oleh Negara sebagai jawaban terhadap kondisi sosial yang diskriminatif. ${ }^{51}$ Tindakan affirmatif ini pada dasarnya hadir dengan memiliki sebuah tujuan jangka panjang yang berfungsi dalam mengurangi bentuk diskriminasi antar kelompok. ${ }^{52}$ Tindakan affirmatif akan berbanding lurus dengan keberadaan tujuan hukum berupa keadilan dan kemanfaatan. ${ }^{53}$

Indonesia merupakan salah satu Negara yang memiliki kesadaran terhadap affirmative action. ${ }^{54} \mathrm{Hal}$ ini tercermin dalam UUDNRI Tahun 1945 secara tegas memberikan jaminan perlakuan khusus bagi kelompok masyarakat tertentu sebagai hak untuk memperoleh kesempatan dan manfaat yang sama. Pasal 28H Ayat (2) UUDNRI Tahun 1945 menyatakan "Setiap orang berhak mendapat kemudahan dan perlakuan khusus untuk memperoleh kesempatan dan manfaat yang sama guna mencapai persamaan dan keadilan". UMKM merupakan masyarakatyang sangat memerlukan perlakuan khusus melalui kebijakan afirmatif khususnya di bidang HKI, selama ini UMKM mengalami kesulitan untuk mempromosikan produknya dikarenakan ada ketakutan apabila UMKM mempromosikan produknya yang belum terdaftar ternyata memiliki persamaan dengan produk terdaftar sebelumnya.

Sejalan dengan hal tersebut, ketentuan Pasal 7 ayat (1) Undang-Undang tentang UMKM mengamanahkan kepada Pemerintah dan Pemerintah Daerah untuk menumbuhkan iklim usaha melalui penetapan peraturan perundangundangan dan kebijakan yang meliputi aspek: $a$. pendanaan; $b$. sarana dan prasarana; $c$. informasi usaha; $d$. kemitraan; $e$. perizinan usaha; $f$. kesempatan berusaha; $g$. promosi dagang; dan $h$. dukungan kelembagaan. Lebih lanjut, dalam penumbuhan iklim usaha melalui penetapan peraturan perundang-undangan dan kebijakan dalam aspek promosi dagang, salah satunya ditujukan untuk memfasilitasi pemilikan hak atas kekayaan intelektual atas produk dan desain Usaha Mikro, Kecil, dan Menengah dalam kegiatan usaha dalam negeri dan ekspor, serta mendorong Usaha Mikro, Kecil, dan Menengah untuk memperoleh sertifikat hak atas kekayaan intelektual. Berkaitan dengan hal tersebut maka sudah sepatutnya Pemerintah dalam hal ini Kementerian Hukum dan HAM RI mendorong lahirnya kebijakan

50 Eka NAM Sihombing dan Nur Fatmah G, "Mendorong Keterwakilan Perempuan di Lembaga Legislatif", Jurnal Legislasi, Volume 9 Nomor 4 (2012): 599.

51 Hendri Sayuti, "Hakikat Affirmative Action dalam Hukum Indonesia (Ikhtiar Pemberdayaan yang Terpinggirkan)", Jurnal Menara, Volume 12 Nomor 1 (2013): 41.

52 Ibid.

53 Marten Bunga, "Konsepsi Affirmative Action sebagai Bentuk Penerapan Equality Before The Law dalam Mewujudkan Demokrasi Di Indonesia", Jurnal Legalitas Volume 7 Nomor 1 (2014): 14.

54 Ibid. 
afirmatif yang lebih mendukung UMKM untuk memanfaatkan sistem HKI, berupa pembebasan biaya pendaftaran HKI khususnya bagi Usaha Mikro dan memberi keringanan biaya kepada usaha kecil dan menengah meskipun saat ini berdasarkan Peraturan Pemerintah Nomor 45 Tahun 2016 terdapat perbedaan biaya pendaftaran bagi UMKM, namun sebagaimana diuraikan terdahulu, bahwa biaya tersebut masih dianggap memberatkan, khususnya bagi usaha mikro yang notabene memiliki kekayaan bersih paling banyak Rp50.000.000,00 (lima puluh juta rupiah).

Pembebasan biaya bagi Usaha mikro dan memberi keringanan bagi Usaha Kecil dan Menengah didasarkan atas sinkronisasi dan analogi terhadap Pasal 12 huruf b UndangUndang Nomor 20 Tahun 2008 tentang UMKM yang membebaskan biaya perizinan bagi usaha mikro dan memberi keringanan biaya kepada usaha kecil dan menengah. Keberhasilan Pemerintah dalam mendorong UMKM melalui kebijakan afirmatif untuk memperoleh sertfikat HKI juga berdampak dapat membantu para pelaku UMKM memperluas sumber untuk mendapatkan pembiayaan dan jasa/produk keuangan lainnya yang disediakan oleh perbankan dan lembaga keuangan bukan bank, baik yang menggunakan sistem konvensional maupun sistem syariah, hal ini dikarenakan berdasarkan ketentuan Pasal 16 ayat (3) UU Nomor 28 Tahun 2014 tentang Cipta, Pasal 108 ayat (1) UU Nomor 13 Tahun 2006 tentang
Paten, baik hak cipta maupun hak paten secara tegas dinyatakan dapat dijadikan jaminan fidusia. ${ }^{55}$ Namun, berbeda halnya dengan hak merek yang tidak dinyatakan secara tegas dalam UU Nomor 20 Tahun 2016 tentang Merek dan Indikasi Geografis bahwa hak merek dapat dijaminkan melalui skema fidusia begitu juga halnya dengan bidang HKI yang lain seperti Desain Industri, rahasia dagang dan desain tata letak sirkuit terpadu.

Meskipun di dalam ketentuan Pasal 1 angka 2 UU Nomor 42 Tahun 1999 tentang Jaminan Fidusia dinyatakan bahwa benda tak berwujud termasuk kategori benda yang dapat dijadikan jaminan fidusia, akan tetapi perlu ditegaskan kembali bahwa seluruh bidang HKI dapat dijadikan objek jaminan fidusia dalam setiap Undang-Undang di bidang HKI, penegasan ini sejalan dengan amanah tersirat pada sidang ke -13 United Nations Comission on International Trade Law (UNCITRAL), WorkingGroup VI on Security Interest, secured transaction law, New York19-23 Mei 2008 yang mengharapkan kepada masing-masing Negara membuat aturan $\mathrm{HKI}$ sebagai jaminan, tentunya dengan tidak bertentangan dengan ketentuan HKI yang ada di masing-masing Negara dan juga perjanjian internasional di bidang HKI yang telah dibuat antar Negara. ${ }^{56}$ Selain itu penegasan HKI sebagai jaminan fidusia juga sangat penting untuk menunjukkan konsistensi dan harmonisasi antar peraturan perundangundangan, juga untuk lebih memperkuat dan

55 Berdasarkan ketentuan Pasal 1 angka 2 UU Nomor 42 Tahun 1999, Jaminan Fidusia adalah hak jaminan atas benda bergerak baik yang berwujud maupun yang tidak bewujud dan benda tidak bergerak khususnya Bangunan yang tidak dapat dibebani hak tanggungan sebagaimana dimaksud dalam Undang-undang Nomor 4 Tahun 1996 tentang Hak Tanggungan yang tetap berada dalam penguasaan Pemberi Fidusia, sebagai agunan bagi pelunasan uang tertentu, yang memberikan kedudukan yang diutamakan kepada Penerima Fidusia terhadap kreditor lainnya.

56 Sri Mulyani, "Pengembangan Hak Kekayaan intelektual sebagai Collateral (agunan) untuk Mendapatkan Kredit Perbankan di Indonesia", Jurnal DInamika Hukum, Volume 12 Nomor 3 (2012): 577. 
menjamin pelaksanaan fidusia dengan objek $\mathrm{HKI}$, terkhusus HKI yang dimiliki oleh UMKM. Penegasan ini juga dihrapakan dapat menjaga geliat kegiatan usaha sektor UMKM dan dapat mendukung pemajuan usaha UMKM serta meningkatkan perekonomian nasional. Untuk itu diperlukan terobosan hukum dengan melakukan percepatan perubahan berbagai peraturan perundang-undangan yang terkait dengan HKI. Hal ini sejalan dengan apa yang disampaikan oleh Hendri Sayuti bahwa salah satu sarana terpenting untuk menerapkan affirmative action ini adalah adanya jaminan pelaksanaannya dalam konstitusi dan UndangUndang. ${ }^{57}$

\section{Penutup}

Mengingat peran UMKM yang sangat strategis dalam perekonomian nasional di mana kegiatan usahanya mampu memperluas lapangan kerja dan memberikan pelayanan ekonomi secara luas kepada masyarakat, maka perlindungan $\mathrm{HKI}$ harus dapat dimanfaatkan secara optimal oleh UMKM, hal ini sangat penting, agar produk-produk yang diproduksi oleh UMKM di Indonesia dapat dilindungi dan tidak mudah untuk ditiru oleh orang lain sehingga dapat merugikan kepentingan UMKM. Namun terdapat berbagai hambatan dalam pemanfaatan sistem HKI oleh UMKM yang disebabkan beberapa faktor, antara lain, Prosedur pendaftaran yang panjang dan kompleks, Biaya registrasi/pendaftaran yang mahal dan lemahnya penegakan hukum bagi pelanggaran $\mathrm{HKI}$.

Dalam rangka menumbuhkembangkan iklim usaha yang mendukung UMKM,juga perlu diupayakan peningkatan kemampuan dan peran serta kelembagaan UMKM secara integratif, dengan memberikan kesempatan yang sama bagi UMKM dan bahkan harus diberikan keistimewaan khususnya di bidang kekayaan intelektual melalui kebijakankebijakan affirmatif. Karena, hanya dengan perlakuan khusus dalam kebijakan affirmatif tersebut, dapat dicapai persamaan perlakuan dalam perlindungan dan pemenuhan hak konstitusional setiap warga Negara.

Adapun kebijakan afirmatif yang harus segera diwujudkan guna mendukung pemajuan usaha UMKM adalah penghapusan biaya pendaftaran permohonan HKI bagi Usaha Mikro dan pemberian keringanan bagi Usaha Kecil dan Menengah serta memberikan penegasan bahwa seluruh bidang HKI harus dapat dijadikan jaminan fidusia. Untuk itu diperlukan terobosan hukum dengan melakukan percepatan perubahan berbagai peraturan perundangundangan yang terkait dengan $\mathrm{HKI}$, diantaranya UU Nomor 20 Tahun 2016 tentang Merek dan Indikasi Geografis, UU No. 30 Tahun 2000 tentang Rahasia Dagang, UU Nomor 31 Tahun 2001 tentang Desain Industri, UU Nomor 32 Tahun 2000 tentang Desain Tata Letak Sirkuit Terpadu serta Peraturan Pemerintah Nomor 45 Tahun 2016 Perubahan Kedua atas Peraturan Pemerintah Nomor 45 Tahun 2014 tentang Jenis dan Tarif atas Jenis Penerimaan Negara Bukan Pajak yang berlaku pada Kementerian Hukum dan Hak Asasi Manusia, khususnya yang terkait dengan penetapan tarif PNBP permohonan pendaftaran HKI

$57 \quad$ Hendri Sayuti, op. cit., hlm 43. 


\section{Daftar Pustaka}

\section{Buku}

Budiarto, Rachmawan et.al., Pengembangan UMKM antara Konseptual dan Pengalaman Praktis, (Yogyakarta : Gadjah Mada University Press, 2015).

Djulaeka, Konsep Perlindungan Hak Kekayaan Intelektual (Perspektif Kajian Filosofis HaKI Kolektif Komunal), (Malang : Setara Press, 2014).

Efendi, Joenaidi dan Johnny Ibrahim, Metode Penelitian Hukum (Normatif dan Empiris), (Jakarta : Prenada Media, Cet. Kedua, 2018).

Marzuki, Peter Mahmud Penelitian Hukum, (Jakarta : Prenadamedia Group, 2011).

Muhammad, Abdul Kadir Kajian Ekonomi Hak Kekayaan Intelektual, (Bandung : Citra Aditya Bakti, 2007).

Purwaningsih, Endang, Hak Kekayaan Intelektual (HKI) dan Lisensi, (Bandung : Mandar Maju, 2012).

Wiradirja, Imas Rosidawati dan Fontian Munzil, Pengetahuan Tradisional dan Hak Kekayaan Intelektual (Perlindungan Pengetahuan Tradisional Berdasarkan Asas Keadilan Sui Generis Intellectual Property System), (Bandung : Refika Aditama, 2018).

BPHN-Kementerian Hukum dan HAM RI, "Draft Naskah Akademik Peraturan PerundangUndangan RUU Tentang Merek", (Jakarta : BPHN-Kementerian Hukum dan HAM RI, 2015).

Direktorat Jenderal Hak Kekayaan Intelektual - Departemen Kehakiman dan HAM RI, Membangun Usaha Kecil Menengah Berbasis Pendayagunaan Sistem Hak Kekayaan Intelektual (Kiat Melindungi Usaha), (Jakarta : DJHKI-Dep. Kehakiman dan HAM RI, 2004).

\section{Makalah/Artikel/Prosiding/Hasil Penelitian dan lain-lain}

Bunga, Marten "Konsepsi Affirmative Action sebagai Bentuk Penerapan Equality Before The Law dalam Mewujudkan Demokrasi Di Indonesia", Jurnal Legalitas (2014)

Hapsari, Pradnya Paramita et.al, Pengaruh Pertumbuhan Usaha Kecil Menengah (UKM) terhadap Pertumbuhan Ekonomi Daerah (Studi di Pemerintah Kota Batu), Jurnal Wacana (2014).

Mulyani, Sri "Pengembangan Hak Kekayaan intelektual sebagai Collateral (agunan) untuk
Mendapatkan Kredit Perbankan di Indonesia", Jurnal Dinamika Hukum, (2012)

Sayuti, Hendri "Hakikat Affirmative Action dalam Hukum Indonesia (Ikhtiar Pemberdayaan yang Terpinggirkan)", Jurnal Menara (2013)

Sihombing, Eka NAM dan Nur Fatmah G, "Mendorong Keterwakilan Perempuan di Lembaga Legislatif", Jurnal Legislasi (2012)

Sinaga, V. Selvie, "Faktor-Faktor Penyebab Rendahnya Penggunaan Hak Kekayaan Intelektual di Kalangan Usaha Kecil Menegah Batik", Jurnal Hukum Ius Quia lustum (2014)

Supriyanto, "Pemberdayaan Usaha Mikro, Kecil, dan Menengah (UMKM) Sebagai Salah Satu Upaya Penanggulangan Kemiskinan", Jurnal Ekonomi \& Pendidikan, (2006)

Taufik, Ade Irawan "Evaluasi Regulasi Dalam Menciptakan Kemudahan Berusaha Bagi UMKM", Jurnal Rechtsvinding (2017)

\section{Internet}

Arif Wicaksono, "UMKM Dongkrak Pertumbuhan Ekonomi Yogyakarta Lampaui Nasional", MetroTV News, http://ekonomi.metrotvnews. com/mikro/8N0V8mAk-umkm-dongkrakpertumbuhan-ekonomi-yogyakarta-lampauinasional (diakses 01 Oktober 2018)

Berinovasi.com, "Pentingnya Kekayaan Intelektual dalam Dunia Usaha" , Berinovasi.com, http:// berinovasi.com/wp-content/uploads/2018/01/ Ebook-Pentingnya-Kekayaan-Intelektual-dalamDunia-Usaha.pdf (diakses 5 Agustus 2018).

Bisnis UKM, "Pentingnya HKI bagi UKM", Bisnis UKM, https://bisnisukm.com/pentingnya-hkibagi-ukm.html (diakses 6 Agustus 2018)

Klinik Hukum, "Affirmative Action", Hukum Online, http://www.hukumonline.com/klinik/detail/ cl6904/affirmative-action (diakses 1 Agustus 2018).

LEI-02, "Ini dia yang sering dilanggar dalam bidang Kekayaan Intelektual”, Legal Era Id., https://legaleraindonesia.com/ini-dia-yangsering-dilanggar-dalam-bidang-hak-kekayaanintelektual/(diakses 6 Agustus 2018)

Lei-KO2, "Ini Kontribusi Koperasi dan UMKM Terhadap PDB Nasional 2017", Legal Era. Id, https://legaleraindonesia.com/inikontribusi-koperasi-dan-umkm-terhadap-pdbnasional-2017/, (diakses 5 Agustus 2018)

Maizal Walfajri, "3000 UKM dapat Fasilitas Hak Cipta dan Merek Gratis", Kontan http://keuangan. 
kontan.co.id/news/3000-ukm-dapat-fasilitashak-cipta-merek-gratis (diakses 5 Agustus 2018).

Matthew, Sean"Analisis Terhadap Pengaturan Hukum Hak Merek Yang Dijaminkan Melalui Mekanisme Fidusia", http://kanalhukum.id/kanalis/analisisterhadap-pengaturan-hukum-hak-merek-yangdijaminkan-melalui-mekanisme-fidusia/43 (diakses 6 Agustus 2018)

NN, "Paparan Kepala Dinas Kopersai dan UKM Provinsi Sumatera Utara pada Rakornas Bidang KUMKM Tahun 2018", http://www.depkop. go.id/uploads/tx_rtgfiles/10._Paparan_ Rakornas_Yogyakarta_2018_-_Sumatera_Utara. pdf (diakses 6 Agustus 2018)

Purnama, Candra "Perlindungan Hukum Produk UMKM melalui HKI (Hak Kekayaan Intelektual)", http://dinkop-umkm.jatengprov.go.id/assets/ upload/files/HAK\%20MEREK\%20UMKM. pdfhttp://www.hukumonline.com/klinik/detail/ cl6904/affirmative-action (diakses 5 Agustus 2018)
Putri Syifa Nurfadilah, "UMKM Mampu Dongkrak Pertumbuhan Ekonomi" , Kompas. com, https://ekonomi.kompas.com/ $\mathrm{read} / 2018 / 07 / 10 / 200246326 / \mathrm{umkm}$-mampudongkrak-pertumbuhan-ekonomi (diakses 5 Agustus 2018)

Sri Handi Lestari, "Kontribusi UMKM terhadap Pertumbuhan Ekonomi Jatim Diklaim Terus Tumbuh Positif", Surabaya Tribun News, http://surabaya.tribunnews.com/2018/06/22/ kontribusi-umkm-terhadap-pertumbuhanekonomi-jatim-diklaim-terus-tumbuh-positif (diakses 1 Oktober 2018)

Sudaryanto, et.al, "Strategi Pemberdayaan UMKM Menghadapi Pasar Bebas Asean", https://www. kemenkeu.go.id/sites/default/files/strategi\%20 pemberdayaan\%20umkm.pdf (diakses 5 Agustus 2018) 